\title{
Verification of anti-wrinkle and heat aging inhibition effects of Rosa multiflora flower extract
}

\author{
Jin A Hyun ${ }^{1}$, Eun Bin Kang ${ }^{1}$, Young Seok Kim ${ }^{1}$, Hyo Seok Lee ${ }^{1}$, Hyun Ji Kwon ${ }^{1}$, \\ Seok Hyun Beom ${ }^{1}$, Eun Young Choi ${ }^{1}$, Ga Eun Park ${ }^{2}$, Min Jung Jang ${ }^{3}$, Bong Jeun $\mathrm{An}^{1 *}$ \\ ${ }^{1}$ Department of Cosmeceutical Science, DaeguHanny University, Gyeongsan 38578, Korea \\ ${ }^{2} R \& D$ Team, Humancosmetic Co., Ltd., Gyeongsan 38578, Korea \\ ${ }^{3}$ Department of Advanced Materials, Dongseo University, Busan 47011, Korea
}

\section{찔레꽃(Rosa multiflora) 추출물의 주름개선 및 열노화 저해 활성}

\author{
현진아 $^{1} \cdot$ 강은빈 $^{1} \cdot$ 김영석 $^{1} \cdot$ 이효석 ${ }^{1} \cdot$ 권현지 $^{1} \cdot$ 범석현 $^{1}$ • \\ 최은영 ${ }^{1} \cdot$ 박가은 $^{2} \cdot$ 장민정 $^{3} \cdot$ 안봉전 $^{1 *}$ \\ ${ }^{1}$ 대구한의대학교 화장품약리학과, ${ }^{2}$ 휴먼코스메틱(주, ${ }^{3}$ 동서대학교 신소재화학공학전공
}

\begin{abstract}
In the present study, the anti-wrinkle effects of an extract of Rosa multiflora were assessed to determine whether it can be used as a heat aging-prevention cosmetic. High-performance liquid chromatography (HPLC) was used to determine the content of astragalin (the active ingredient) in the extract. The protein expression levels of MMP-1, procollagen, and transient receptor potential vanilloid (TRPV-1), which is a heat receptor thermal aging inhibitor, were measured. The protein expression of RMA, which has the best anti-wrinkle effect, was also measured. Consequently, the anti-wrinkle and heat-aging inhibition effects of $R$. multiflora extract and the content of astragalin resulting from each extraction condition were confirmed. Additional research is needed to verify whether astragalin has a direct effect on heat aging. However, the potential of astragalin as a heat aging-inhibitor is apparent considering the results of previous studies that have demonstrated that $R$. multiflora extract has excellent antioxidant activity and that $\boldsymbol{R}$. multiflora extract inhibits the expression of certain proteins. Therefore, $R$. multiflora extract is a potentially useful cosmetic for the prevention or alleviation of wrinkles and heat aging.
\end{abstract}

Keywords : Rosa multiflora, thermal aging, heat, anti-aging

서 론

피부 노화는 크게 내인성 노화(intrinsic aging)와 외인성 노화(extrinsic aging) 두 가지로 구분되며, 외인성 노화의 다 양한 환경 요인들 중에 자외선과 열은 피부를 노화시키는 데 중요한 요인으로 작용한다(Choi 등, 2016).

최근 환경오염으로 인하여 오존층이 파괴되면서 자외선이
강해지고 이로 인한 진피층 파괴로 주름개선에 대한 관심이 증가하고 있다. 이와 더불어 지구 온난화로 인하여 기온이 점 점 상승하고 있어 열노화에 대한 연구도 주목받고 있는 추세 이다. 자외선과 열은 사계절 내내 존재하며, 일상생활에서 흔 히 접하는 노화의 원인이기 때문에 자외선과 열로부터 노화 된 피부를 보호하고 개선하는 것이 가장 중요하다. 열노화란 피부가 열을 받으면 피부의 온도를 상승시켜 노

*Corresponding author. E-mail : anbj@dhu.ac.kr, Phone :+82-53-819-1435, Fax :+82-53-819-1435

Received 17 June 2021; Revised 10 September 2021; Accepted 28 September 2021.

Copyright (c) The Korean Society of Food Preservation.

This is an Open Access article distributed under the terms of the Creative Commons Attribution Non-Commercial License (http://creativecommons.org/licenses/by-nc/4.0) which permits unrestricted non-commercial use, distribution, and reproduction in any medium, provided the original work is properly cited. 
화를 촉진시키는 새로운 피부노화의 개념이다. 열은 직접 전 도, 순환 전류, 대류 또는 가열된 물체의 적외선(열) 복사에 의해 전달되며, 다양한 전달 수단에도 불구하고 최종 열에너 지는 동일하고 피부온도를 상승시키기도 한다(Seo와 Chung, 2006). 또한, 사람의 피부는 스마트폰, 헤어드라이어, 스토브 등의 전자기기에서 발생하는 열에 자주 노출되어 피부온도가 높아지고, 피부 노화가 진행되기도 한다(Son 등, 2018). 이와 같이 사람의 피부는 매일 자외선과 적외선에 노출되며, 사람 의 피부 온도는 여름 한낮의 직사광선에서 $15-20$ 분 이내에 $40-43^{\circ} \mathrm{C}$ 까지 상승한다는 연구결과도 보고되어 있다(Seo와 Chung, 2006). 이것으로 보아 피부에서 노화의 원인이 태양 빛 속의 자외선뿐만 아니라, 열(적외선)도 포함된다는 것을 확인할 수 있다.

찔레(Rosa multiflora)는 장미과(Rosaceae)에 속하는 식물 로 산이나 들의 기슭이나 계곡 등에서 쉽게 볼 수 있으며, 약 성의 효능이 좋기 때문에 어느 하나 버릴 것 없이 오랫동안 한방에서 사용되었다. 또한, 찔레의 꽃과 열매, 뿌리, 씨앗 등 다양한 부위의 항산화 효과와 항염증 효과, 항균 효과, 발모 등의 우수한 소재로 알려져 있다.

이러한 찔레의 알려진 유효성분으로는 flavonoid의 계열인 quercetin 배당체(multinoside $\mathrm{A}$, multinoside $\mathrm{B}$, quercitrin 등), kaempferol 배당체(multiflorin A, multiflorin B, afzelin, astragalin 등), 탄닌 계열의 methyl gallate 및 과실의 홍색색 소인 lycopene 등이 보고되었다(Kim 등, 2018). 이 중에 찔레 꽃의 유효성분으로 알려진 astragalin은 다양한 식물의 플라 보노이드 배당체 중 하나이며, 생물학적 관점에서 효과적인 화 합물로 여러 연구를 통하여 항암, 항염증, 항산화 등과 같은 광범위한 약리학적 특징을 가지고 있는 것으로 알려져 있다. 이러한 astragalin의 항산화 효과로는 내독소로 인한 산화스 트레스 억제를 한다고 연구가 되어 있다(Riaz 등, 2018). 또한, astragalin이 열에 의해 증가된 reactive oxygen species(ROS) 에 의한 신호전달체계에 의해 MMP 발현이 증가된다(Choi 등, 2016)는 보고에 따라 열에 의해 증가된 활성산소를 억제 시켜 열노화에 도움이 될 것으로 예상된다. 뿐만 아니라, 열 수용체인 TRPV-1 이온통로는 $43^{\circ} \mathrm{C}$ 이상의 열자극과 $\mathrm{pH} 5.4$ 이하의 산성자극에 대해 반응하는 특성을 지닌 것으로 알려 져 있다. 또한, 열자극 및 매운 자극의 정보를 전달할 뿐만 아니라, 염증 등의 환경에 의해 통증의 증가를 유발시키는 데 관여하는 것으로 알려져 있다(Jung, 2011).

본 연구에서는 찔레꽃의 열노화 화장품 소재로서의 활용 여부를 알아보고자 찔레꽃을 추출하여 주름개선효과를 측정 하고, 유효성분 함량측정을 위해 Astragalin을 가지고 HPLC 분 석을 진행하였으며, 항주름 검증을 위한 MMP-1, procollagen 과 열노화 저해 검증을 위한 열수용체인 TRPV-1(transient receptor potential vaniloid)의 단백질 발현을 측정하여 검증하
였다.

\section{재료 및 실험 방법}

\section{재료 및 시료추출}

본 실험에 사용한 찔레꽃은 청도 각남면 예리 2리에서 2019년에 채집 후 자연 건조시켜 $4^{\circ} \mathrm{C}$ 냉장실에 보관하고 사 용하였다. 추출 방법은 침지법과 열수법을 사용하였다. 건조 된 시료 $100 \mathrm{~g}$ 을 갈지 않고 그대로 사용하여 $2 \mathrm{~L}$ 의 용매를 넣어서 추출하였다. 열수는 $50^{\circ} \mathrm{C}$ 에서 $24 \mathrm{~h}$ 동안 추출하는 것 을 2회 반복하였으며, $70 \%$ ethanol과 $70 \%$ acetone 추출물은 실온에서 $24 \mathrm{~h}$ 동안 침지시켜 추출한 것을 2 회 반복하였다. 각각의 추출액을 여과지(No. 20 filter paper, Hyundai Micro Co., Ltd., Seoul, Korea)로 여과, 농축, 동결건조하였다. 열수 (RMW)의 수율은 $6.93 \%, 70 \%$ ethanol(RME)의 수율은 $23.66 \%, 70 \%$ acetone(RMA)의 수율은 $20.08 \%$ 이었다. 이렇 게 동결건조시킨 각 추출물들은 $4^{\circ} \mathrm{C}$ 냉장실에 보관하였으며, 본 실험의 시료로 사용하였다(Fig. 1).

\section{시약 및 기기}

실험에 사용된 시약은 다음과 같다. N-succinyl-(L-Ala) $3^{-}$ p-nitroanailide, Elastase from porcine pancreas, Collagenase (From Clostridium histohyticum, type-1), 4-phenylazobenzyloxycarbonyl-Pro-Leu-Gly-Pro-D-Arg 등은 Sigma Aldrich Co., Ltd.(St. Louis, MO, USA), TRPV-1은 Thermo Fisher Scientific(Waltham, Massachusetts, USA)에서 구입하였으며, MMP-1, procollagen 2차 antibodies는 Santa Cruz(Biotech., texas, $\mathrm{CA}, \mathrm{USA}$ )에서 구입하여 사용하였다. 세포주 $\mathrm{Hs} 68$ dermal fibrobast cell(Hs68 cell)과 $\mathrm{HaCaT}$ Keratinocyte cell 은 ATCC(Manassas, VA, USA)에서 구매하여 사용하였다. 세포 배양을 위한 fetal bovine serum(FBS), Dulbecco's modified eagle medium(DMEM), trypan blue stain, trypsinEDTA, 3-[4,5-dimethylthiazol-2-yl]-2,5-dipheyl-tetrazolium bromide(MTT) 시약은 Sigma Aldrich Co., Ltd.에서 구입하 였다. 유효성분 함량 분석에 사용된 Astragalin은 Chemfaces (Wuhan, Hubei, China)에서 구입하였다. 본 실험에 사용된 기기는 ELISA reader(Spectra max 190, Moleculer devices, Sunnyvate, USA), UV/VIS spectrophotometer(Hitachi, Tokyo, Japan), freeze drier(Ilshin, Korea), microscope(Olympus Co., Ltd., Tokyo, Japan), rotary vacuum evaporator(Rikakikai Co., Ltd., Tokyo, Japan), digital reciprocating shaker(Daihan scientific Co., Ltd., Gangwondo, Korea), western imaging system (CAS-400SM, Davinch-K Co., Ltd., Seoul, Korea), $\mathrm{CO}_{2}$ incubator(VS-9160GC, Hanbaek Scientiffic Co., Deajeon, Korea), UPLC H-Class(Waters, Massachusetts, USA), UV 


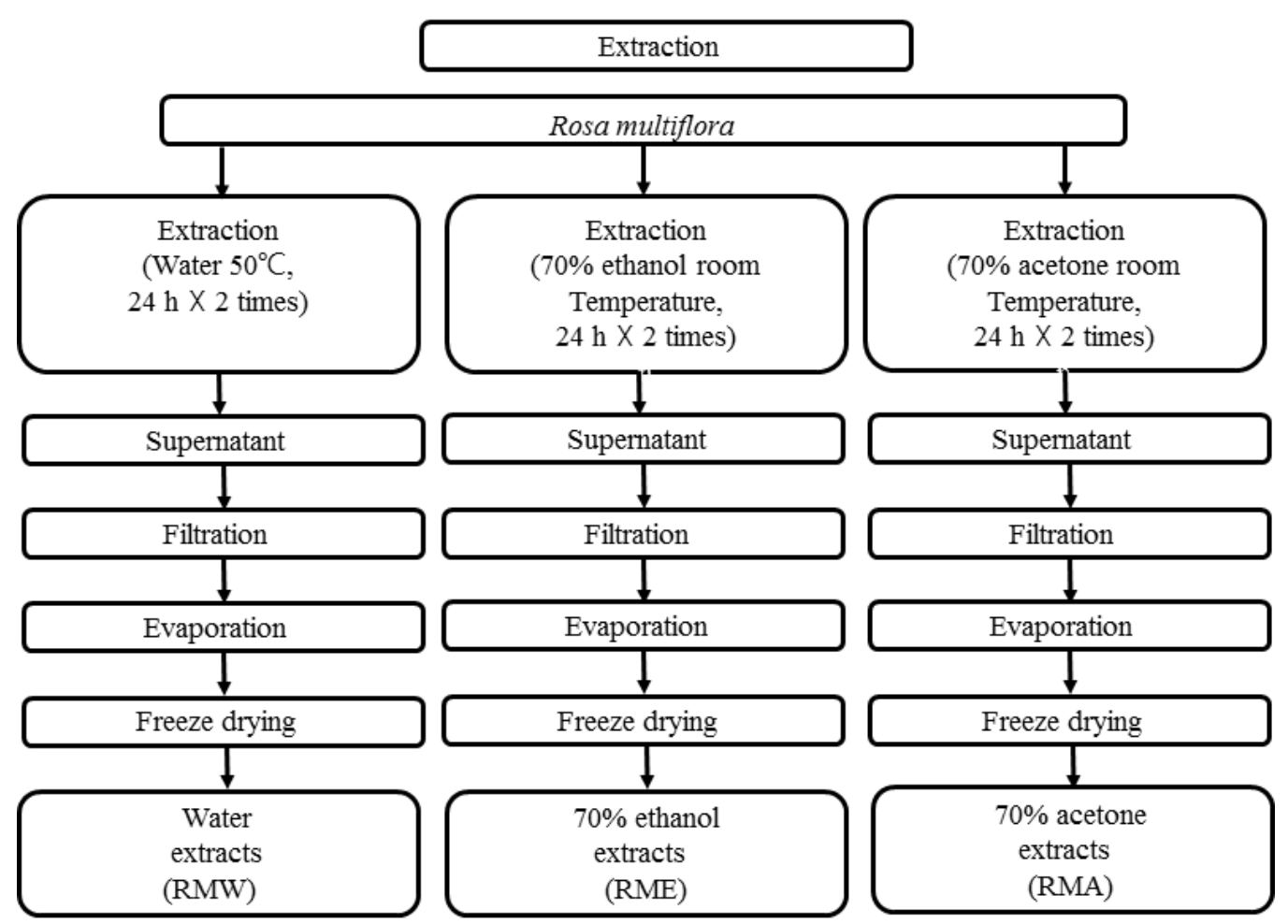

Fig. 1. The procedure for extraction from Rosa multiflora flower.

detector(BAP ACQUITY UPLC TUV detector) (Waters, Massachusetts, USA), ACQUITY UPLC BEH C18 $(2.1 \times 100$ $\mathrm{mm}, 1.7 \mu \mathrm{m})($ Waters, Massachusetts, USA)를 사용하였다.

\section{Elastase 저해 효과 측정}

Elastase 저해활성은 Cannell 등(1988)의 방법을 참고하여 실험을 진행하였다. $N$-syccinyl-(L-Ala) $)_{3}-p$-nitroanailide를 사 용하여 $36^{\circ} \mathrm{C}$ 에서 $25 \mathrm{~min}$ 간 기질로부터 생성되는 p-nitroanilide 의 양을 ELISA reader로 흡광도 $(405 \mathrm{~nm})$ 를 측정하였다. 그 후, 농도별로 희석한 샘플을 $40 \mu \mathrm{L}$ 로 취하고 $50 \mathrm{mM}$ Tris-HCl buffer(pH 8.6)에 녹인 elastase $(0.5$ unit $/ \mathrm{mL})$ 용액 $40 \mu \mathrm{L}$ 를 가한 후 기질로 $50 \mathrm{mM}$ Tris $\operatorname{buffer}(\mathrm{pH}$ 8.6)에 녹인 $N$ succinyl-(L-Ala) $)_{3}-p$-nitroanailide을 첨가하여 $20 \mathrm{~min}$ 간 반응 후 결과를 측정하였다. 양성 대조군으로는 epigallocatechin gallate(EGCG)를 사용하였다.

\section{Collagenase 저해활성 측정}

Collagenase 저해활성 측정은 Cannell 등(1988)의 방법에 따라 측정하였다. $0.1 \mathrm{M}$ tris- $\mathrm{HCl} \operatorname{buffer}(\mathrm{pH}$ 7.5)에 $4 \mathrm{mM}$ $\mathrm{CaCl}_{2}$ (Junsei Chemical Co., Ltd., Tokyo, Japan)를 첨가하여 buffer를 만든다. 4-Phenylazobenyloxycarbonly-Pro-Leu-GlyPro-D-Arg $(0.3 \mathrm{mg} / \mathrm{mL})$ 을 buffer에 녹여 $0.25 \mathrm{~mL}$ 의 기질과
시료 $0.1 \mathrm{~mL}$ 를 혼합한 후 collagenase $(0.2 \mathrm{mg} / \mathrm{mL})$ 를 $0.15 \mathrm{~mL}$ 를 첨가하여 실온에서 $20 \mathrm{~min}$ 간 반응시킨다. 반응시간이 끝 나면 $6 \%$ citric acid $0.5 \mathrm{~mL}$ 를 넣어 반응을 정지시킨 후, ethyl acetate $1.5 \mathrm{~mL}$ 를 첨가하여 흡광도 $(320 \mathrm{~nm})$ 를 측정하였다.

\section{세포 배양}

본 실험에서 이용한 Hs68 dermal fibrobast cell, HaCaT keratynocyte cell은 $10 \%$ FBS와 $1 \%$ penicillin/streptomycin $(100 \mathrm{U} / \mathrm{mL})$ 을 첨가한 DMEM 배지를 사용하였으며, $37^{\circ} \mathrm{C}$, $5 \% \mathrm{CO}_{2}$ incubator에 적응시켜 계대배양하였다. $\mathrm{HaCaT}$ cell과 Hs68 cell은 phosphate buffer saline(PBS)로 세척 후 trypsin$\mathrm{EDTA}$ 를 사용해서 세포를 수확한 후 계대배양하였다.

\section{열자극에 따른 세포 생존율 측정}

열노화 저해효과를 측정하기 위하여 Son 등(2018)의 방법 을 참고하여 실험을 진행하였다. 96 well plate에 Hs68 cell은 $2 \times 10^{4} \mathrm{cell} / \mathrm{well}, \mathrm{HaCaT}$ cello $5 \times 10^{3} \mathrm{cell} / \mathrm{well}$ 이 되도록 분주 한 후 incubator에서 $37^{\circ} \mathrm{C}, 5 \% \mathrm{CO}_{2}$ 조건으로 $24 \mathrm{~h}$ 동안 배양 시키고 나서 $44^{\circ} \mathrm{C}$ 로 설정된 incubator에 $30 \mathrm{~min}$ 간 넣어 열자 극을 준 뒤, 시료를 $25,50,100,250,500 \mu \mathrm{g} / \mathrm{mL}$ 농도별로 $0.02 \mathrm{~mL}$ 첨가 후 $\mathrm{HaCaT}$, Hs68 cell 모두 $37^{\circ} \mathrm{C}, 5 \% \mathrm{CO}_{2}$ incubator에서 $6 \mathrm{~h}$ 배양하였다. 그 후 $2.5 \mathrm{mg} / \mathrm{mL}$ 농도의 
MTT 용액을 $0.02 \mathrm{~mL}$ 첨가하여 $4 \mathrm{~h}$ 동안 반응시켰다. 반응 후에 배양액을 최대한 제거하고, 각 well당 dimethyl sulfoxide (DMSO, DUKSAN, Gyeonggido, Korea)을 $0.1 \mathrm{~mL}$ 를 가하 여 실온에서 $30 \mathrm{~min}$ 간 충분히 formation을 녹여 ELISA reader로 흡광도 $(540 \mathrm{~nm})$ 를 측정하였다.

\section{Western blot을 통한 단백질 발현량 측정}

6well plate에 세포주 $\mathrm{HaCaT}$ cell은 $5 \times 10^{5}$ cells/well, $\mathrm{Hs} 68$ cell은 $2 \times 10^{5} \mathrm{cell} / \mathrm{well}$ 이 되도록 분주하고, $37^{\circ} \mathrm{C}, 5 \%$ $\mathrm{CO}_{2}$ incubator에서 $24 \mathrm{~h}$ 동안 배양시킨다. 그 뒤에 배양액을 혈청 무첨가 DMEM 배지로 교환한 후 주름개선효과 및 열노 화 저해효과를 측정을 위해 $\mathrm{Hs} 68$ cell과 $\mathrm{HaCaT}$ cell을 $44^{\circ} \mathrm{C}$ 의 열로 자극하여 각 시료용액을 농도별로 처리 후 $37^{\circ} \mathrm{C}, 5 \%$ $\mathrm{CO}_{2}$ incubator에서 $6 \mathrm{~h}$ 배양시켰다.

그 뒤 배지를 제거하고 PBS로 1회 세척 후 모든 세포는 RIPA buffer로 처리하여 세포를 용해시키고, 원심분리기를 이 용하여 $4^{\circ} \mathrm{C}, 12,000 \mathrm{rpm}$ 에서 $15 \mathrm{~min}$ 동안 원심분리시킨 뒤 얻은 상등액을 새 튜브에 옮긴 후 단백질 정량을 실시하였다. 그 후 전기영동시켜 단백질을 분리해 주었다. 전기영동이 끝 난 후 membrane에 분리된 단백질을 옮겨주고 membrane은 digital reciprocating shaker 기기를 이용하여 5\% skim milk 로 $2 \mathrm{~h}$ blocking 한 다음 primary antibody로 $3 \mathrm{~h}$ 반응시켜준 후 TBST solution으로 $10 \mathrm{~min}$ 3회 세척을 반복하였다. 그 다 음에 특정 단백질에 primary antibody가 붙은 membrane을 각 항체의 숙주에 해당하는 secondary antibody를 $1 \mathrm{~h}$ 동안 반응시켰다. 그리고 TBST solution으로 $10 \mathrm{~min} 3$ 번 세척을 반복한 뒤 Davinch Western imaging system을 이용하여 단 백질 발현량을 측정하였다.

\section{Astragalin의 $\mathrm{HPLC}$ 분석}

Astragalin을 정밀하게 달아 메탄올에 녹여 $1,000 \mu \mathrm{g} / \mathrm{mL}$ 표준용액을 제조하였다. 표준물질인 astragalin을 희석하여 5, $10,50,100,500,1,000 \mu \mathrm{g} / \mathrm{mL}$ 의 농도로 준비하였다. 이후 $\mathrm{HPLC}$ 로 분석하여 피크별 머무름 시간을 확인하고, 농도별 평균면적을 구하고 X축은 표준물질의 농도, $\mathrm{Y}$ 축은 면적으로 하여 검량선을 작성하였다.

HPLC 조건은 Table 1에 요약되어 있으며, 분석 칼럼은 ACQUITY UPLC BEH C18(2.1×100 mm, $1.7 \mu \mathrm{m})$ 을 이용 하였다. 이동상 $\mathrm{A}$ 는 $0.1 \%$ formic acid in deionized water을, 이동상 $\mathrm{B}$ 는 acetonitrile을 이용하였다. 분석시간 $0 \mathrm{~min}$ 에서 $5 \mathrm{~min}$ 까지는 이동상 A 95\%로 용리하고 $35 \mathrm{~min}$ 에서 $45 \mathrm{~min}$ 까지 이동상 $\mathrm{B}$ 만 $100 \%$ 가 되도록 한 다음 $50 \mathrm{~min}$ 에서 55 $\min$ 까지 처음과 같은 상태로 유지하면서 $0.1 \mathrm{~mL} / \mathrm{min}$ 의 유속 으로 분석을 실시했으며, 분석 칼럼의 온도는 $40^{\circ} \mathrm{C}$ 로 일정하
Table 1. Analytical conditions of HPLC for analysis of astragalin

\begin{tabular}{|c|c|c|c|}
\hline Detector & \multicolumn{3}{|c|}{$\begin{array}{l}\text { UV detector (BAP ACQUITY UPLC } \\
\text { TUV detector) }\end{array}$} \\
\hline Wavelength & \multicolumn{3}{|l|}{$254 \mathrm{~nm}$} \\
\hline Column & \multicolumn{3}{|c|}{$\begin{array}{l}\text { ACQUITY UPLC BEH C18 } \\
(2.1 \times 100 \mathrm{~mm}, 1.7 \mu \mathrm{m})\end{array}$} \\
\hline \multirow{8}{*}{ Gradient } & \multicolumn{3}{|c|}{$\begin{array}{l}\text { A: } 0.1 \% \text { formic acid in deionized water } \\
\text { B: acetonitrile }\end{array}$} \\
\hline & Time (min) & A $(\%)$ & B $(\%)$ \\
\hline & Initial & 95.0 & 5.0 \\
\hline & 5 & 95.0 & 5.0 \\
\hline & 35 & 0.0 & 100.0 \\
\hline & 45 & 0.0 & 100.0 \\
\hline & 50 & 95.0 & 5.0 \\
\hline & 55 & 95.0 & 5.0 \\
\hline Flow rate & \multicolumn{3}{|l|}{$0.1 \mathrm{~mL} / \mathrm{min}$} \\
\hline Injection volume & \multicolumn{3}{|l|}{$1.0 \mu \mathrm{L}$} \\
\hline Column temp & \multicolumn{3}{|l|}{$40^{\circ} \mathrm{C}$} \\
\hline
\end{tabular}

게 하였다.

\section{통계분석}

모든 실험은 3 회 반복하여 측정하였다. 결과는 평균값 \pm 표 준편차로 나타내고 통계적 분석은 통계분석 프로그램인 IBM SPSS Statistics(version 20.0, IBM Corp., Armonk, NY, USA) 를 사용하였다. 유의성 검증을 위하여 one-way ANOVA를 실 시하였으며, 사후검증은 $\mathrm{p}<0.05$ 수준으로 Duncan's multiple range test에 의해 분석하였다.

\section{결과 및 고찰}

\section{Elastase 저해효과}

찔레꽃 추출물의 주름개선 효능을 보기 위하여 Elastase 저 해효과를 측정한 결과, 낮은 농도인 $5 \mu \mathrm{g} / \mathrm{mL}$ 에서부터 최고 농도인 $1,000 \mu \mathrm{g} / \mathrm{mL}$ 까지 모두 농도 의존적인 효과를 보였으 며, $\mathrm{RMW}$ 를 제외한 나머지 추출물은 $50 \mu \mathrm{g} / \mathrm{mL}$ 의 농도에서 부터 양성 대조군인 EGCG보다 높은 저해활성을 보였다. 양 성대조군보다 높은 저해활성을 보인 $50 \mu \mathrm{g} / \mathrm{mL}$ 에서 $\mathrm{RMW}$ 는 $1.14 \%, \mathrm{RME}$ 는 $21.83 \%, \mathrm{RMA}$ 는 $28.11 \%$ 의 저해효과를 나타 내었다(Fig. 2). Cho 등(2014)의 연구결과에서 도화 열수 추 출물의 elastase 저해능은 $1,000 \mu \mathrm{g} / \mathrm{mL}$ 에서 $10 \%$ 미만이라고 


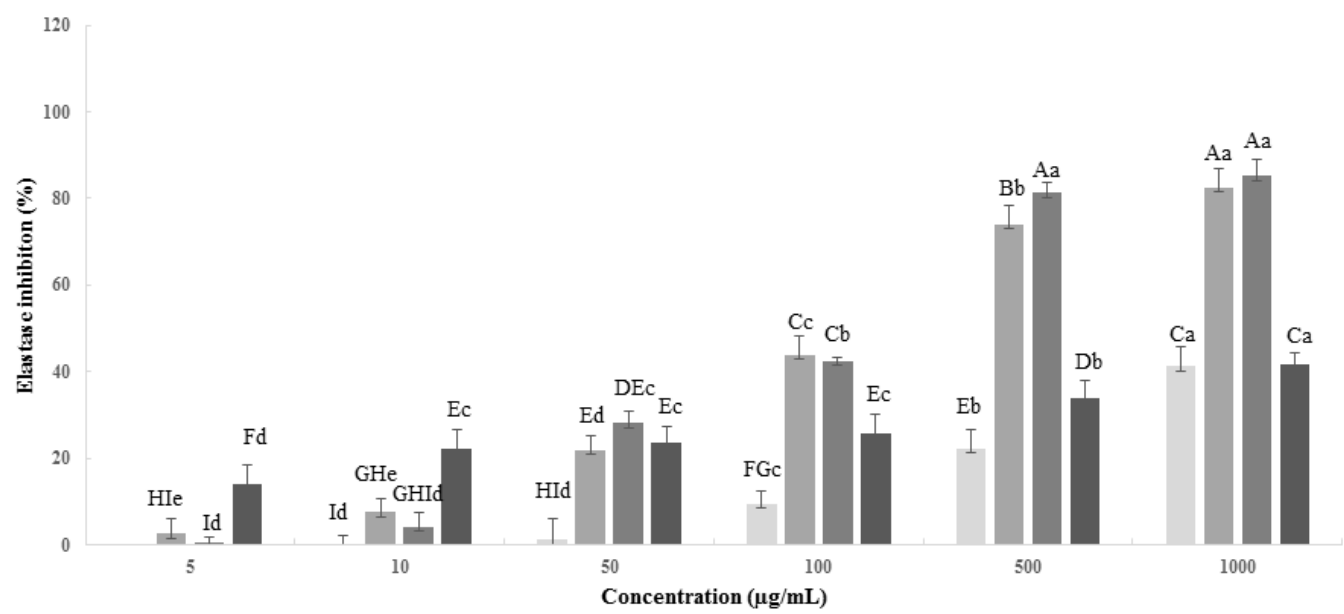

Fig. 2. Elastase inhibition activity of Rosa multiflora flower extracts.

The data represent the mean \pm SD of three separate experiments (A-I Values with different capital letters are significantly different at the $\mathrm{p}<0.05$ among various concentration. ${ }^{\mathrm{a}-\mathrm{e}}$ Values with different letter in the same sample are significantly different at $\mathrm{p}<0.05$ by Duncan's multiple range test).

RMW, R. multiflora flower water extract; $\quad$ RME, R. multiflora flower 70\% ethanol extract; $\quad$ RMA, R. multiflora flower 70\% acetone extract; EGCG, epigallocatechin gallate.

하였으며, 맥문동 열매의 물과 메탄올 추출물은 각각 $43.23 \%$ 와 $32.29 \%$ 의 저해효과를 나타내었다. 이 결과와 비교하여 최 고농도인 $1,000 \mu \mathrm{g} / \mathrm{mL}$ 에서 $\mathrm{RMW}, \mathrm{RME}$ 와 $\mathrm{RMA}$ 는 각각 $41.15 \%, 82.53 \%, 85.18 \%$ 로 보아 RMA와 RME는 대조군인 $\mathrm{EGCG}$ 보다 높은 효과를 보여주면서 다른 추출물들보다 상대 적으로 높은 효능을 보여 주름개선 기능성 소재로서 긍정적 인 영향을 미칠 것으로 사료된다.

\section{Collagenase 저해활성 측정 결과}

찔레꽃 추출물의 주름개선 효능을 보기 위하여 collagenase 저해활성을 측정한 결과는 낮은 농도인 $31 \mu \mathrm{g} / \mathrm{mL}$ 부터 최고 농도인 $500 \mu \mathrm{g} / \mathrm{mL}$ 모두 농도 의존적인 효과를 보였다. 최고 농도인 $500 \mu \mathrm{g} / \mathrm{mL}$ 에서 $\mathrm{RMW}$ 는 $40.95 \%$, RME는 $43.12 \%$, $\mathrm{RMA}$ 는 $85.48 \%$ 의 저해활성을 나타내었다(Fig. 3). Cho 등 (2014)의 연구결과, 맥문동 꽃 추출물은 $1,000 \mu \mathrm{g} / \mathrm{mL}$ 에서 메

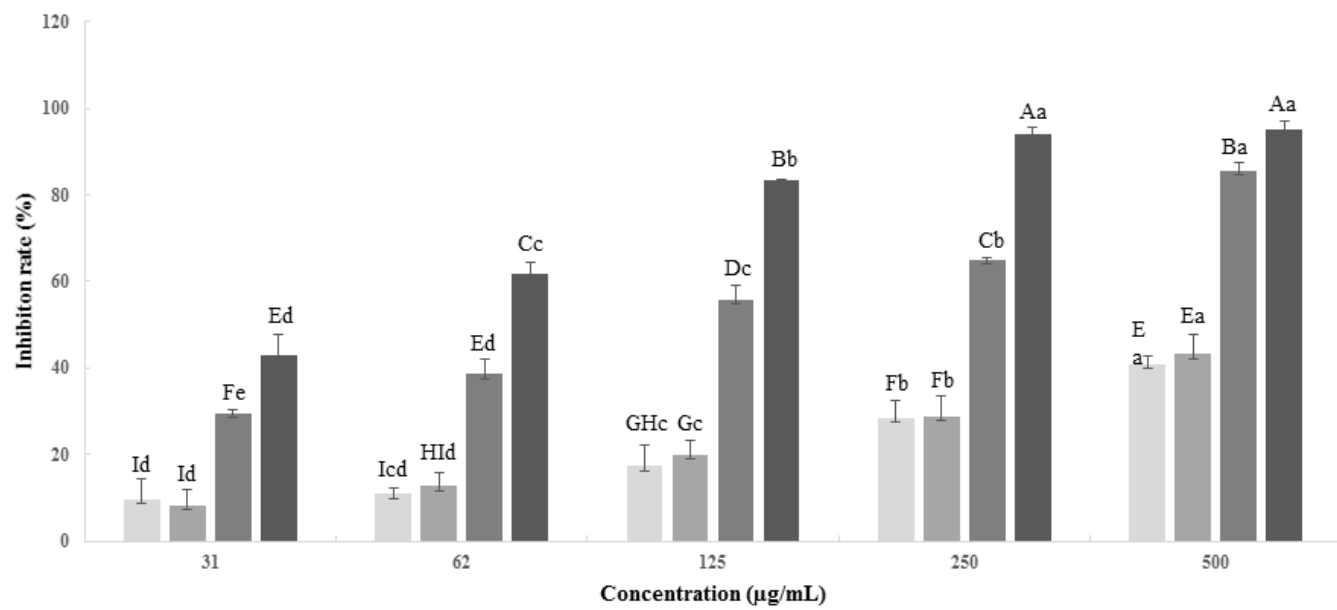

Fig. 3. Collagenase inhibition activity of Rosa multiflora flower extracts.

The data represent the mean \pm SD of three separate experiments (A-I Values with different capital letters are significantly different at the $\mathrm{p}<0.05$ among various concentration. ${ }^{\mathrm{a}-\mathrm{e}}$ Values with different letter in the same sample are significantly different at $\mathrm{p}<0.05$ by Duncan's multiple range test).

RMW, R. multiflora flower water extract; $\quad$ RME, R. multiflora flower 70\% ethanol extract; $\quad$ RMA, R. multiflora flower 70\% acetone extract; EGCG, epigallocatechin gallate. 
탄올 추출물은 $41.71 \%$, 물 추출물은 $31.11 \%$ 의 collagenase 저해능을 보였고, 도화의 물과 에탄올 추출물은 각각 $17.0 \%$ 와 $25.0 \%$ 의 collagenase 저해능을 보였다. 화류 한약재인 선 복화, 홍화, 감국의 에탄올 추출물은 각각 $34.06 \%, 26.97 \%$ 그리 고 $23.33 \%$ 의 collagenase 저해능을 나타내었다(Cho 등, 2014). 이 결과와 비교하여 찔레꽃 추출물이 더 우수한 collagenase 저해활 성을 나타내었으며, 주름개선 기능성 소재로서 가치 및 가능
성이 높을 것으로 사료된다.

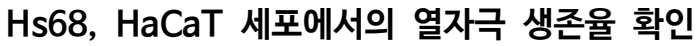

$44^{\circ} \mathrm{C}$ 열자극을 주고 샘플을 $25,50,100,250,500 \mu \mathrm{g} / \mathrm{mL}$ 의 농도로 처리하였을 때 Hs68 cell의 생존율을 Fig. 4에 나타 내었고, $\mathrm{HaCaT}$ cell의 생존율은 Fig. 5에 나타내었다. Hs68 cell에 $44^{\circ} \mathrm{C}$ 의 열자극만 주었을 때 약 $60 \%$ 의 사멸을 보였으

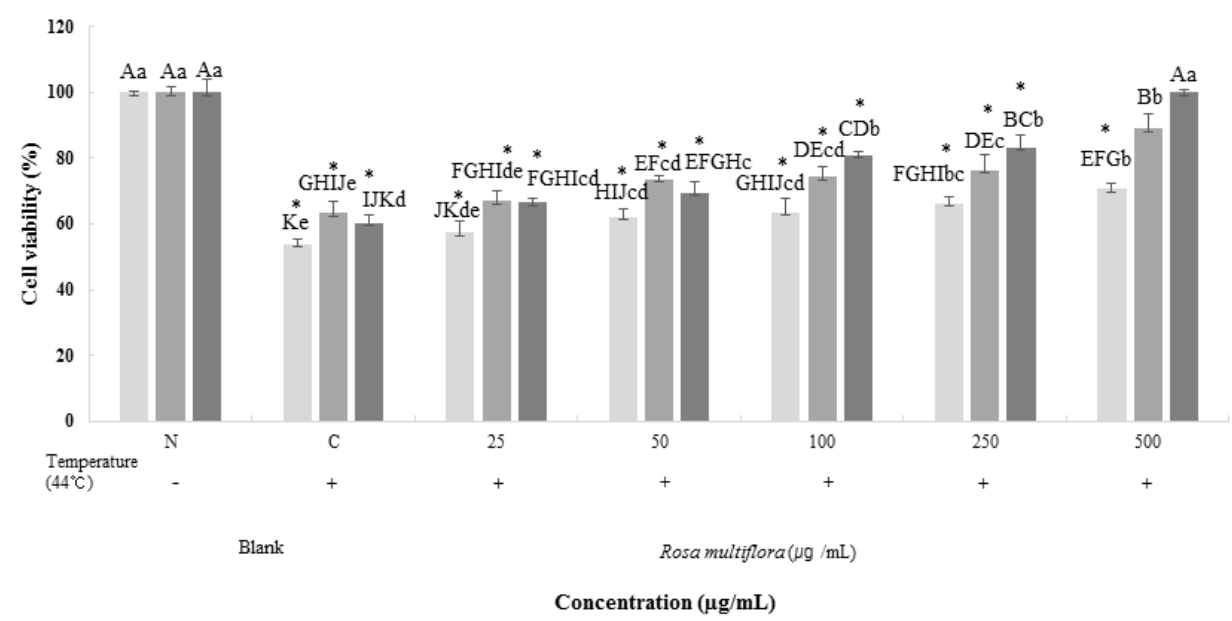

Fig. 4. Cell viability on $44^{\circ} \mathrm{C}$ temperature of $\mathrm{Hs} 68$ cell treated with Rosa multiflora flower extracts.

$\mathrm{N}, 44^{\circ} \mathrm{C}$ temperature not treated; $\mathrm{C}, 44^{\circ} \mathrm{C}$ temperature treated. The data represent the mean $\pm \mathrm{SD}$ of three separate experiments (A-K Values with different capital letters are significantly different at the $\mathrm{p}<0.05$ among various concentration. ${ }^{\mathrm{a}-\mathrm{e}}$ Values with different letter in the same sample are significantly different at $\mathrm{p}<0.05$ by Duncan's multiple range test and significantly different at $\mathrm{p}<0.05$ by Tukey test and significant as compared to Normal. " $\mathrm{p}<0.05$ ).

RMW, R. multiflora flower water extract; RME, R. multiflora flower 70\% ethanol extract; $\quad$ RMA, R. multiflora flower $70 \%$ acetone extract.

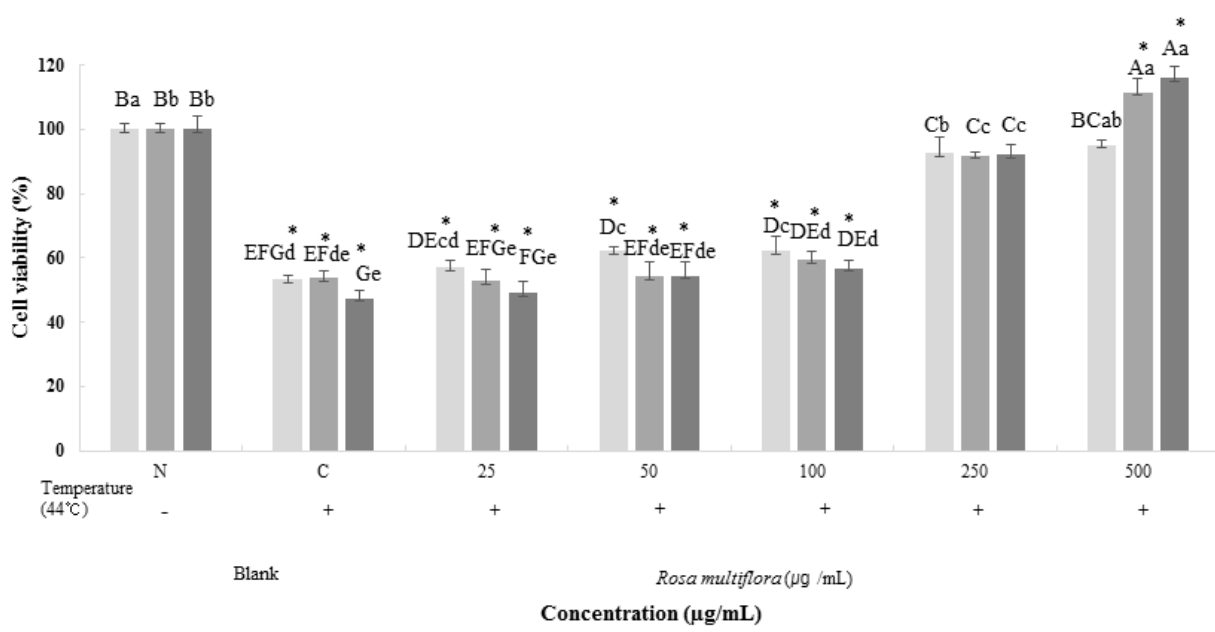

Fig. 5. Cell viability on $44^{\circ} \mathrm{C}$ temperature of HaCaT cell treated with Rosa multiflora flower extracts.

$\mathrm{N}, 44^{\circ} \mathrm{C}$ temperature not treated; $\mathrm{C}, 44^{\circ} \mathrm{C}$ temperature treated. The data represent the mean $\pm \mathrm{SD}$ of three separate experiments (A-G Values with different capital letters are significantly different at the $\mathrm{p}<0.05$ among various concentration. ${ }^{\mathrm{a}-\mathrm{e}}$ Values with different letter in the same sample are significantly different at $\mathrm{p}<0.05$ by Duncan's multiple range test and significantly different at $\mathrm{p}<0.05$ by Tukey test and significant as compared to Normal. ${ }^{*} \mathrm{p}<0.05$ ).

RMW, R. multiflora flower water extract; RME, R. multiflora flower 70\% ethanol extract; $\quad$ RMA, R. multiflora flower $70 \%$ acetone extract. 
며, $\mathrm{HaCaT}$ cell에 $44^{\circ} \mathrm{C}$ 의 열자극만 주었을 때 약 $50 \%$ 의 사 멸을 보였다. Hs68 cell에서는 최고농도인 $500 \mu \mathrm{g} / \mathrm{mL}$ 에서 RMW는 $70.71 \%$, RME는 $89.01 \%$, RMA는 $99.90 \%$ 의 생존 율을 나타냈으며, $\mathrm{HaCaT}$ cell에서는 $250 \mu \mathrm{g} / \mathrm{mL}$ 농도에서 모 두 $90 \%$ 이상의 생존율을 나타내었다. 이 결과, 단백질 발현 측정을 위해 농도를 $250 \mu \mathrm{g} / \mathrm{mL}$ 이하로 설정하여 실험을 진 행하였다.

\section{Hs68 cell에서의 western blot을 통한 MMP-1, pro- collagen, TRPV-1 발현 확인}

$44^{\circ} \mathrm{C}$ incubator에서 $30 \mathrm{~min}$ 간 열자극을 준 뒤, 위 실험에
서 가장 좋은 주름개선 효과를 보인 RMA을 처리하여 열노화 관련 단백질인 MMP-1, procollagen과 TRPV-1에 대한 단백 질 발현을 확인하였다. 그 결과, 샘플을 처리하지 않고 열자극 을 주었을 때 MMP-1은 $28.41 \%$ 증가하였으며, procollagen은 $17.5 \%$ 감소하였고, TRPV- 1 은 $100 \%$ 증가하였다. 열자극을 주고 $\mathrm{RMA}$ 을 처리하였을 때 최고농도에서 Control에 비해 MMP-1은 60.94\% 정도 감소하였으며, procollagen은 20.93\% 증가한 것을 볼 수 있었다. 마지막으로 열노화 지표인 TRPV-1 은 Control에 비해 $53.15 \%$ 감소한 것을 확인할 수 있었다 (Fig. 6). Choi 등(2016)의 연구 결과 두날리엘라살리나 추출 물은 $100 \mu \mathrm{g} / \mathrm{mL}$ 에서 control에 비해 MMP-1의 mRNA 발현
(A)

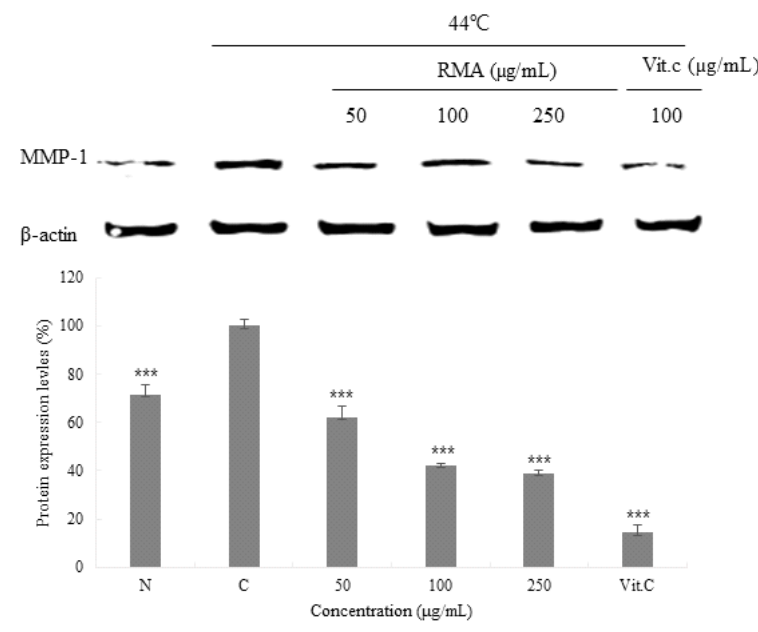

(B)

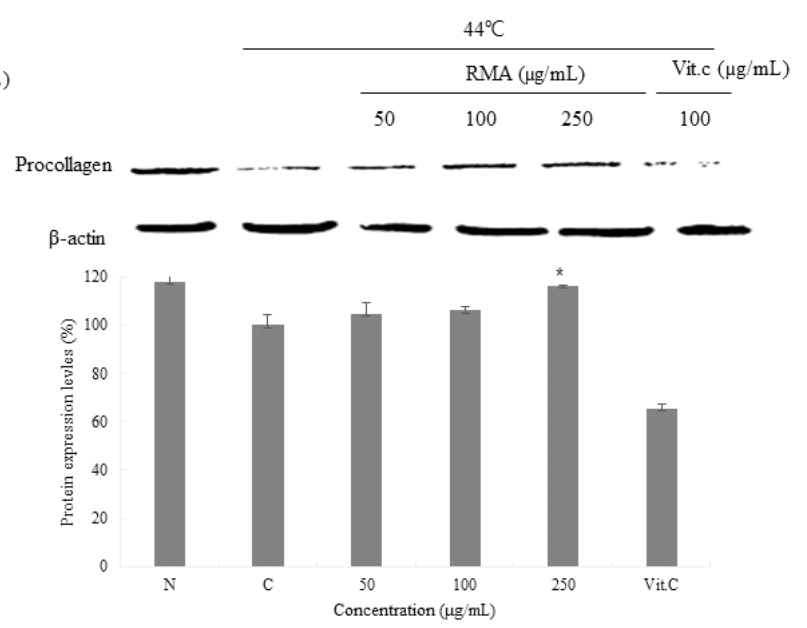

(C)

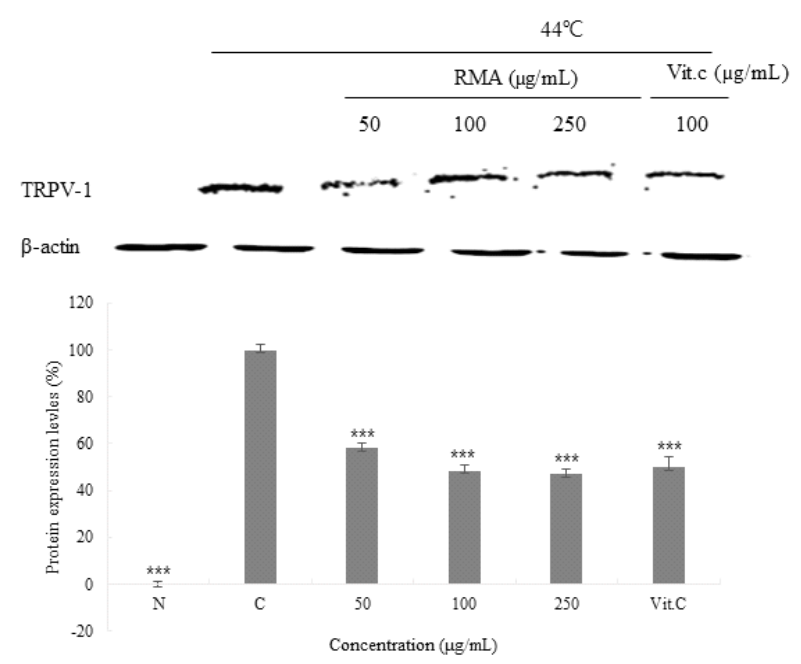

Fig. 6. Inhibitory effects of Rosa multiflora flower $70 \%$ actone extract on the protein levels of MMP-1 and procollagen and TRPV-1 Hs68 dermal fibrobast cells.

$\mathrm{N}, 44^{\circ} \mathrm{C}$ temperature not treated; $\mathrm{C}, 44^{\circ} \mathrm{C}$ temperature treated. (A), MMP-1; (B), procollagen; (C), TRPV-1. The data represent the mean $\pm \mathrm{SD}$ of three separate experiments (significantly different by Tukey test and significant as compared to control. ${ }^{*} \mathrm{p}<0.05,{ }^{* * *} \mathrm{p}<0.01,{ }^{* * *} \mathrm{p}<0.001$ ). 
이 약 $40 \%$ 저해되는 것으로 나타났으며, procollagen은 약 $20 \%$ 증가한 것으로 나타났다. 이 결과와 비교하여 $\mathrm{RMA}$ 는 $100 \mu \mathrm{g} / \mathrm{mL}$ 에서 control에 비해 MMP-1은 57.9\% 단백질 발 현을 저해시켰고, procollagen은 $14.2 \%$ 단백질 발현이 증가 한 것으로 보아 RMA가 열노화 기능성 소재로서 우수한 효 과를 발휘할 수 있을 것으로 사료된다.

\section{$\mathrm{HaCaT}$ cell에서의 western blot을 통한 MMP-1, procollagen, TRPV-1 발현 확인}

$44^{\circ} \mathrm{C}$ incubator에서 $30 \mathrm{~min}$ 간 열자극을 준 뒤 $\mathrm{RMA}$ 을 처리 하여 열노화 관련 단백질인 MMP-1, procollagen과 TRPV-1에
대한 단백질 발현을 확인하였다. 그 결과, 열자극을 주고 샘 플을 처리하지 않았을 때 MMP-1은 $60.55 \%$ 증가하였으며, procollagen $18.21 \%$ 감소하였고, TRPV-1은 $54.7 \%$ 증가하였 다. $\mathrm{RMA}$ 를 처리하였을 때 최고농도에서 Control에 비해 MMP-1은 $70.14 \%$ 감소하였으며, procollagen은 Control에 비해 $16.29 \%$ 증가한 것을 볼 수 있었다. 마지막으로 열노화 지표인 TRPV-1은 Control에 비해 $58.18 \%$ 감소한 것을 확인 할 수 있었다(Fig. 7). 진피층에서의 열노화 효과를 보아 표피 층에서도 RMA가 열노화 기능성 소재로서 우수한 효과를 발 휘할 수 있을 것으로 사료된다.

위의 실험결과를 보았을 때 주름개선 효과를 보기 위한
(A)

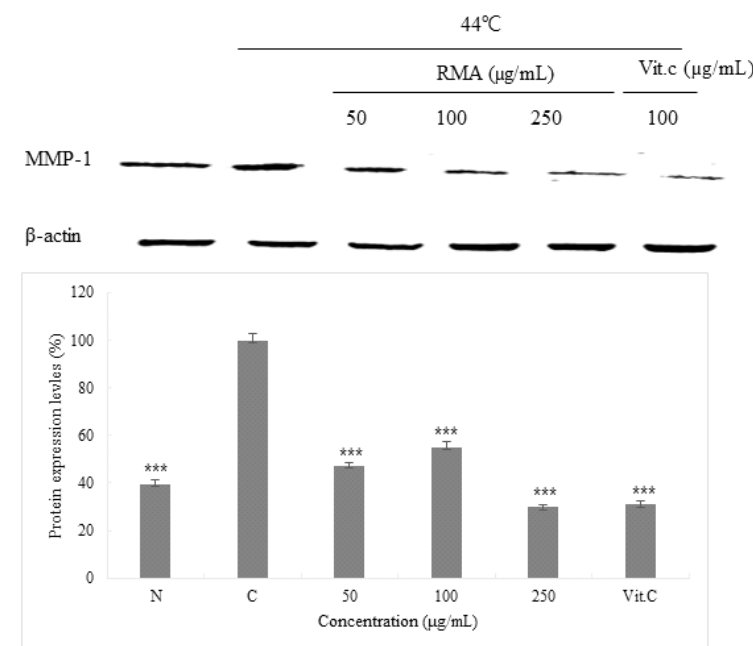

(C)

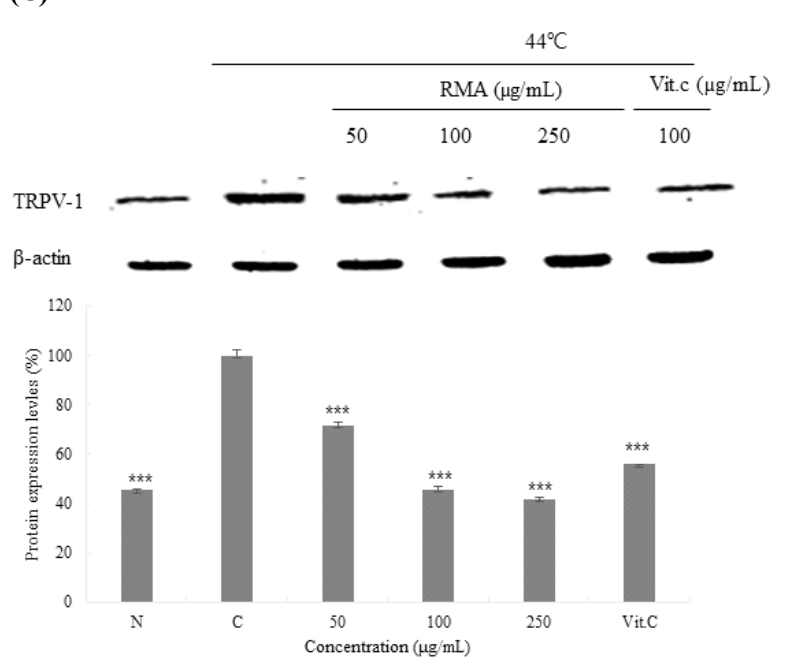

(B)

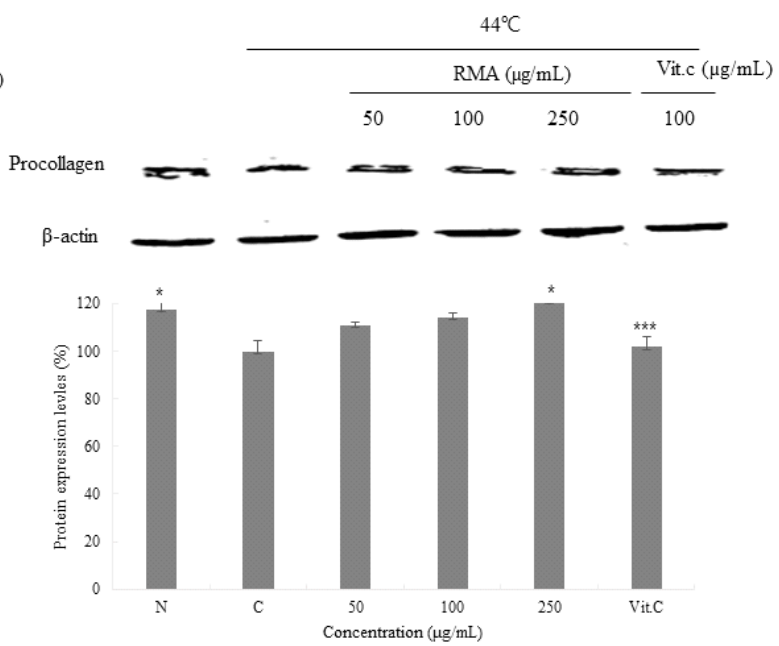

Fig. 7. Inhibitory effects of Rosa multiflora flower $70 \%$ acetone extract on the protein levels of MMP-1 and procollagen and TRPV-1 human keratinocyte cells.

$\mathrm{N}, 44^{\circ} \mathrm{C}$ temperature not treated; $\mathrm{C}, 44^{\circ} \mathrm{C}$ temperature treated. (A), MMP-1; (B), procollagen; (C), TRPV-1. The data represent the mean $\pm \mathrm{SD}$ of three separate experiments (significantly different by Tukey test and significant as compared to control. ${ }^{*} \mathrm{p}<0.05,{ }^{* *} \mathrm{p}<0.01,{ }^{* * *} \mathrm{p}<0.001$ ). 
Elastase 저해 실험과 Collagnase 저해실험, 표피층과 진피층 구성 세포에서의 단백질 발현을 측정한 결과를 보았을 때, 찔 레꽃 추출물이 주름개선 및 열노화 기능성 소재로서의 우수 한 효과를 가질 수 있을 것으로 사료된다.

\section{Astragalin의 HPLC 분석 결과}

찔레꽃(Rosa multiflora) 추출물에 유효성분인 astragalin의 함량을 분석하기 위하여 HPLC 분석을 하였다. astragalin의 검량선을 Fig. 8에 나타낸 것을 토대로 찔레꽃(Rosa multiflora) 추출물들의 평균면적을 구하여 함량을 나타내었다. 이 결과, $\mathrm{RMW}$ 에는 $2.51 \mathrm{mg} / \mathrm{g}$ 의 함량을 보였고, RME는 $14.39 \mathrm{mg} / \mathrm{g}$ 의 함량을 보였으며, RMA는 $44.86 \mathrm{mg} / \mathrm{g}$ 의 함량을 보였다. 이것으로 보아 RMA에서 astragalin의 함량이 제일 많이 보인 것을 확인할 수 있었고, 실험결과를 통틀어서 보았을 때 RMA가 주름개선 효능과 열노화에 효능이 제일 좋았으며, astragalin의 함량이 제일 높은 것으로 보아 astragalin이 주름 개선효능과 열노화에 효과가 있는 것으로 사료된다(Fig. 9).
위 실험 결과를 종합적으로 이루어본 결과 찔레꽃(Rosa multiflora) 추출물의 주름개선 및 열노화 저해 효과와 각 추 출조건별로 astragalin 함량을 확인할 수 있었다. Astragalin이 항산화 작용이 우수하다는 선행연구결과와 찔레꽃(Rosa multiflora) 추출물 자체적인 단백질 발현 억제능을 봤을 때 열노화 저해의 가능성이 충분하며 주름개선 및 열노화를 예 방 또는 완화하는 화장품 및 기능성 소재로서의 사용 가능성 이 있을 것으로 사료되어진다.

\section{요 약}

본 연구에서는 찔레꽃의 열수, $70 \%$ Ethanol, $70 \%$ Acetone 추출물의 열노화 저해 효능을 연구하여 열노화 기능성 화장 품 소재로서 가능성을 확인하였다. Elastase 저해 실험에서는 $\mathrm{RMW}$ 를 제외한 나머지 샘플이 대조군보다 높은 효능을 보 이는 $50 \mu \mathrm{g} / \mathrm{mL}$ 에서 $\mathrm{RMW}, \mathrm{RME}, \mathrm{RMA}$ 은 각각 $1.14 \%$, $21.83 \%, 28.11 \%$ 의 저해활성을 보였으며, collagenase 저해

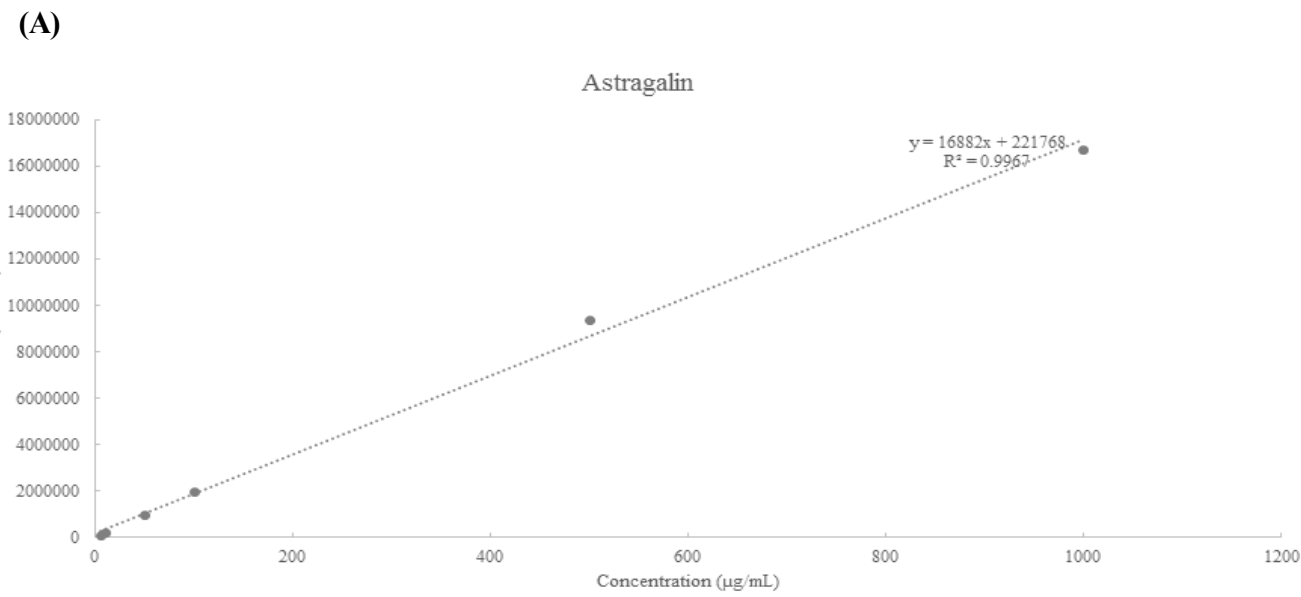

(B)

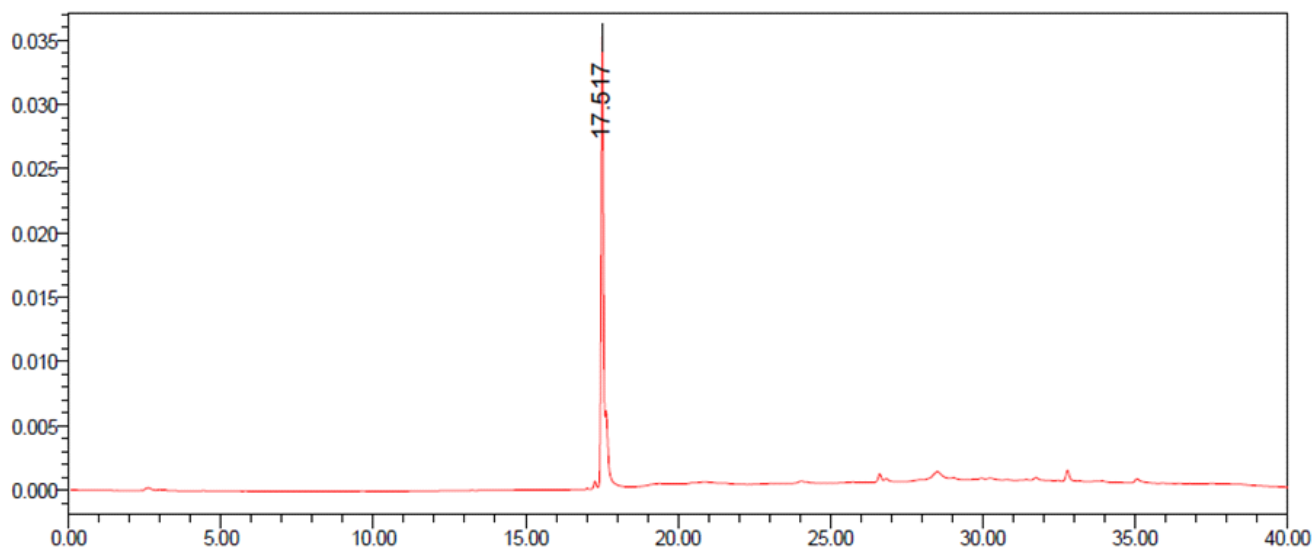

Fig. 8. Standard curve of astragalin and chromatograms of astragalin. 
(A)

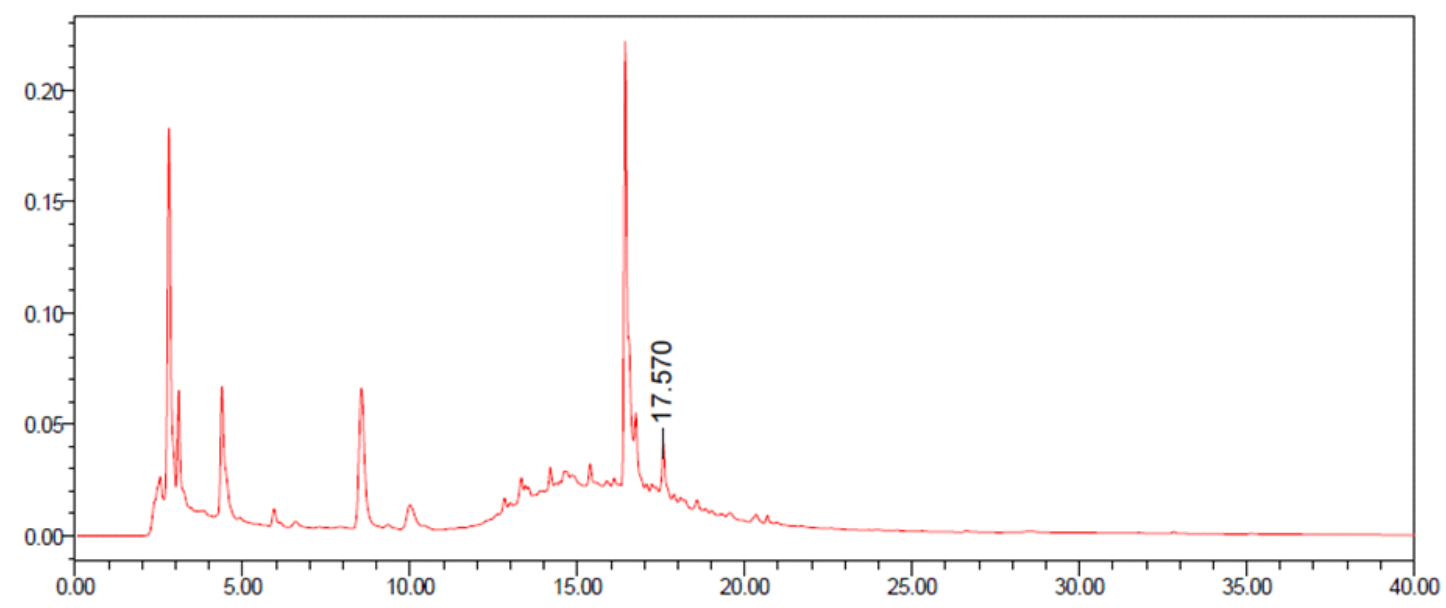

(B)

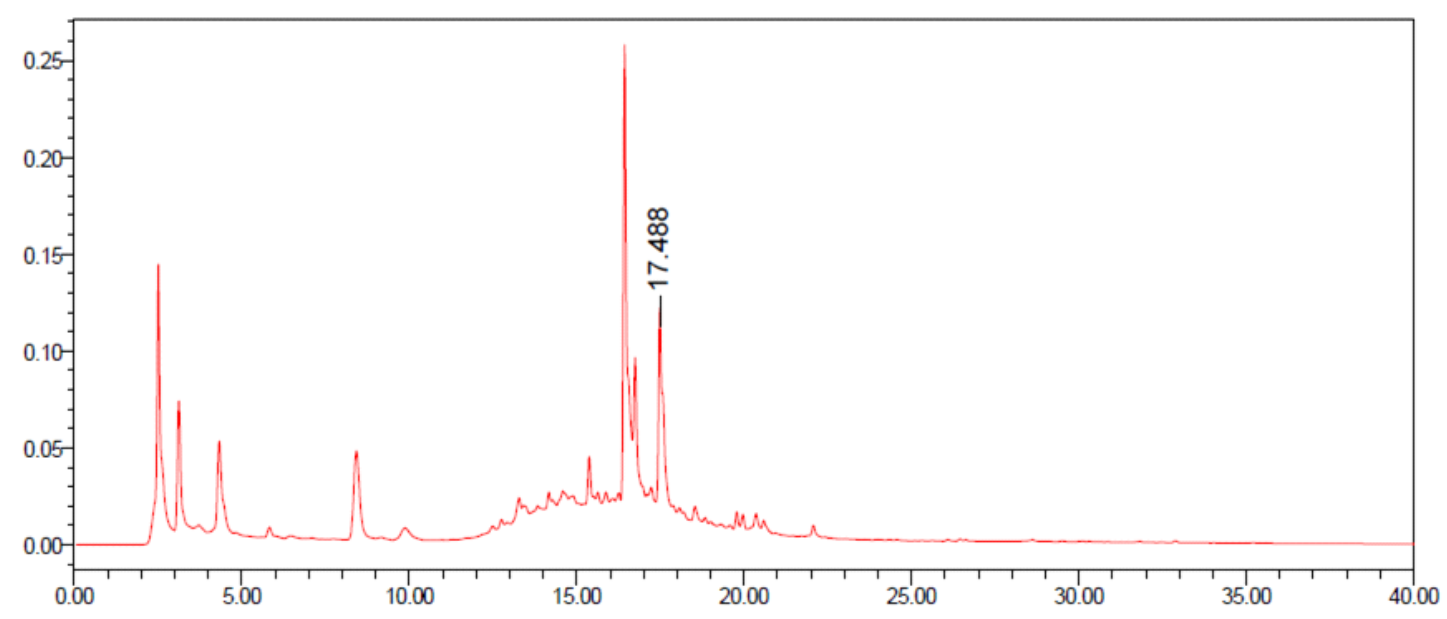

(C)

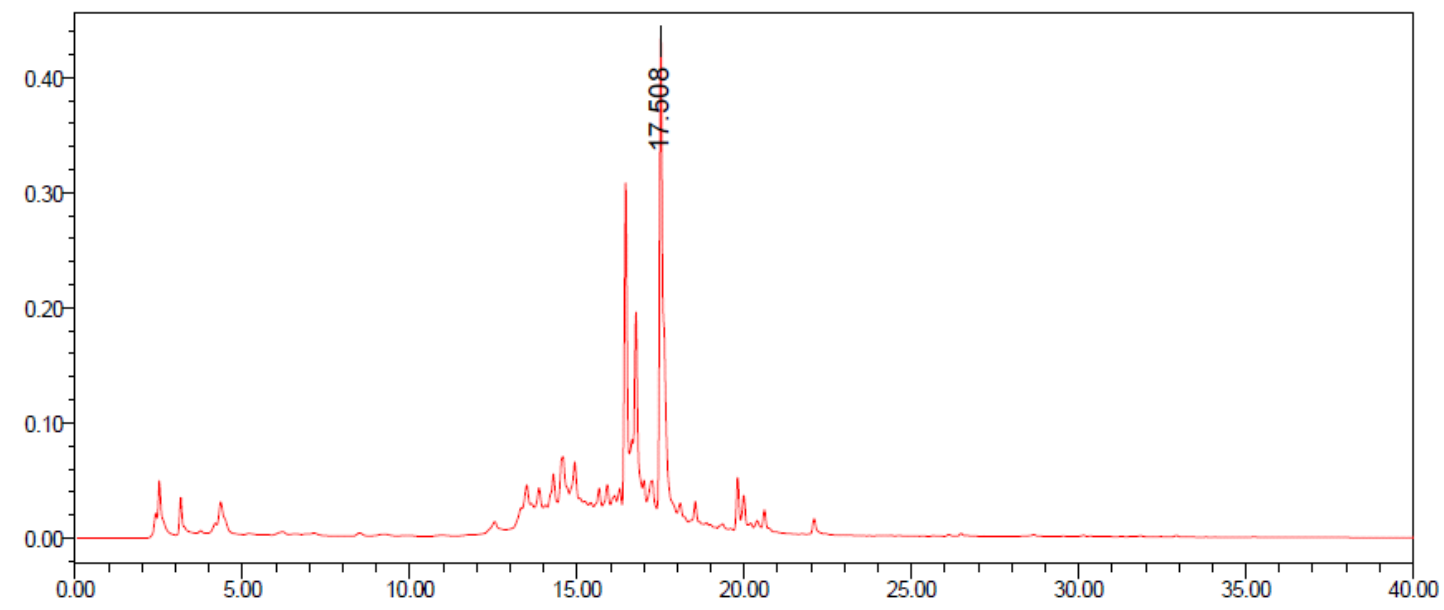

Fig. 9. Chromatograms of Rosa multiflora flower extracts.

A, R. multiflora flower water extract; B, R. multiflora flower $70 \%$ ethanol extract; C, R. multiflora flower $70 \%$ acetone extract. 
실험에서는 최고 농도인 $500 \mu \mathrm{g} / \mathrm{mL}$ 에서 각각 $40.95 \%$, $43.12 \%, 85.48 \%$ 의 저해활성을 나타내었다. 열노화 지표인 TRPV-1 단백질을 활성시키기 위하여 $44^{\circ} \mathrm{C}$ 조건으로 열자극 을 주어 $\mathrm{HaCaT}$ cell과 $\mathrm{Hs} 68$ cell에서 열자극 생존율을 확인 한 결과, $\mathrm{HaCaT}$ cell에서는 $250 \mu \mathrm{g} / \mathrm{mL}$ 에서 모두 $90 \%$ 이상 의 생존율을 보였으며, $\mathrm{Hs} 68$ cell에서는 각각 $70.71 \%$, $89.01 \%, 99.9 \%$ 의 생존율을 보였다. 앞선 활성실험에서 가장 우수한 저해활성을 보인 $70 \%$ Acetone 용매 샘플군인 RMA 의 열노화 저해능을 알아보기 위하여 Western blot을 통해 단 백질 발현을 측정한 결과, 평균적으로 대조군에 비하여 MMP-1 단백질 발현은 약 $60 \%$ 이상 감소되었고, procollagen 단백질 발현은 약 $16 \%$ 증가되었으며, TRPV- 1 단백질 발현 은 약 $50 \%$ 감소한 것을 볼 수 있었다. 찔레꽃의 표준물질인 astragalin의 함량을 RMW, RME, EMA에서 HPLC로 분석한 결과, $\mathrm{RMW}$ 는 $2.51 \mathrm{mg} / \mathrm{g}, \mathrm{RME}$ 는 $14.39 \mathrm{mg} / \mathrm{g}, \mathrm{RMA}$ 는 $44.89 \mathrm{mg} / \mathrm{g}$ 의 함량을 보였다. 위 실험 결과를 통해 찔레꽃 추출물의 주름개선 및 열노화 저해 효과와 각 추출조건별로 astragalin 함량을 확인할 수 있었다. 또한, astragalin이 항산 화 작용이 우수하다는 선행연구결과와 찔레꽃 추출물 자체적 인 단백질 발현 억제능을 봤을 때 열노화 저해의 가능성이 충분하며 주름개선 및 열노화를 예방 또는 완화하는 화장품 및 기능성 소재로서의 사용 가능성이 있을 것으로 사료되어 진다.

\section{Conflict of interests}

The authors declare no potential conflict of interest.

\section{ORCID}

$\begin{array}{ll}\text { Jin A Hyun } & \text { https://orcid.org/0000-0001-5500-2044 } \\ \text { Bong Jeun An } & \text { https://orcid.org/0000-0001-6655-7707 }\end{array}$

\section{References}

Cannell RJ, Kellam SJ, Owsianka AM, Walker JM. Results of a large scale screen of microalgae for the production of protease inhibitors. Planta Med, 54, 10-14 (1988)

Carmichael J, DeGraff WG, Gazdar AF, Minna JD, Mitchell JB. Evaluation of a tetrazolium-based semiautomated colorimetric assay: Assessment of chemosensitivity testing.
Cancer Res, 47, 936-942 (1987)

Choi E, Hong IK, Joo JH, Seok JH, Kim NK. Inhibitory effects of Dunaliella salina extracts on thermallyinduced skin aging. J Soc Cosmet Sci Korea, 42, 57-64 (2016)

Green LC, Wagner DA, Glogowski J, Skipper PL, Tannenbaum SR, Wishnok JS. Analysis of nitrate, nitrite, and [15N] nitrate in biological fluids. Anal Biochem, 126, 131-138 (1982)

Joo EY, Kim JH, Lee YS. Anti-wrinkle and anti-aging activity of liriope platyphylla flower extract. J Investig Cosmetol, 10, 191-200 (2014)

Jung SJ. The role of transient receptor potential channel in pain. Hanyang Med Rev, 31, 2-23 (2011)

Mosmann T. Rapid colormetric assay of nitrate in urine survival: Application to pro liferation and cytotoxicity assays. J Immunol Methods, 65, 55-63 (1983)

Riaz A, Rasul A, Jabeen F, Hussain G, Sarfraz I, Ali M, Zahoor MK, Younis T, Selamoglu Z, Subhani Z. Astragalin: A bioactive phytochemical with potential therapeutic activities. Adv Pharmacol Sci, 2018, 1-15. (2018)

Ryu JY, Rhie SJ, Lim KH, Choi YE, Han HS, Na EJ, Yang HO. Inhibitory effects of prunin on photo-aging in human keratinocytes $(\mathrm{HaCaT})$ damaged by UVB radiation. Asian J Beauty Cosmetol, 17, 139-147 (2019)

Seo J, Chung J. Thermal aging: A new concept of skin aging. J Dermatol Sci Suppl, 2, S13-S22 (2006)

Shin C, Jung H, Kim SH, Ko SG. Research of traditional herbal medicines for anti-aging, inhibition effect of wrinkle and whitening effect in the skin. Korean J Oriental Physiol Pathol, 22, 691-698 (2008)

Son D, Park D, Jung E, Woo H, Kim M. Anti-thermal skin aging activity of aqueous extracts derived from apple mint (Mentha suaveolens Ehrh.) in human dermal fibroblasts. Evidence-Based Complementary and Alternative Medicine: eCAM v.2018, Hindawi (2018)

Yoo BW, Kim HW, Jo HN, Kim JH, Lee TB. Biological activity and cosmetic preservative effects of Rosa multiflora ethanol extracts. Korean J Medicinal Crop Sci, 26, 308316 (2018) 